\title{
Uptake and accumulation of heavy metals by water body and Azolla filiculoides in the Anzali wetland
}

\author{
Mahsa Hassanzadeh ${ }^{1} \cdot$ Rahmat Zarkami $^{1} \cdot$ Roghayeh Sadeghi $^{2}$
}

Received: 29 July 2020 / Accepted: 11 May 2021 / Published online: 22 May 2021

(c) The Author(s) 2021

\begin{abstract}
The Anzali international wetland is a valuable habitat to a wide variety of aquatic flora and fauna. This wetland ecosystem is being threatened due to various pollutants particularly the heavy metals discharging from different point and non-point sources. Concentration of various heavy metals $(\mathrm{Cr}, \mathrm{Pb}, \mathrm{Hg}, \mathrm{Cu}, \mathrm{Zn}, \mathrm{Cd}, \mathrm{Ag}$ and $\mathrm{Ti}$ ) was examined in the water body and Azolla filiculoides (an exotic fern in the Anzali wetland). The samples regarding water and A. filiculoides were randomly carried out in three parts of the wetland (eastern, central and western parts) in May 2015. After preparing and digesting the samples, the concentration of the heavy metals was measured using ICP OES method. The obtained results showed that the concentration of $\mathrm{Zn}$ in water and A. filiculoides samples was higher than other heavy meals in all parts of the wetland $(p<0.05)$. Overall, concentration of the heavy metals was significantly higher in the eastern part of the wetland than other two sampling locations $(p<0.05)$. Also with comparing the concentration of the heavy metals in water and A. filiculoides, it was found that all examined metals (except $\mathrm{Cd}$ and $\mathrm{Ag}$ ) in A. filiculoides had significantly higher concentration than water sample, while $\mathrm{Cd}$ and $\mathrm{Ag}$ in water and A. filiculoides did not have a significant difference with each other. Based on the results, it can be concluded that A. filiculoides can effectively absorb $\mathrm{Cr}, \mathrm{Pb}, \mathrm{Zn}, \mathrm{Hg}, \mathrm{Cu}, \mathrm{Cd}, \mathrm{Ag}$ and $\mathrm{Ti}$ so that it might be used as a valuable species for the bioremediation and the removal of heavy metals from the wetland.
\end{abstract}

Keywords Anzali wetland $\cdot$ Azolla filiculoides $\cdot$ Heavy metals

\section{Introduction}

Wetlands are considered important ecosystems to improve water quality (Zarkami et al.2020). Since the last decades, these valuable ecosystems are facing with various sources of pollutants particularly with the heavy metals (Bonanno and Giudice 2009). Heavy elements are a group of metals and quasi-metals that are toxic and dangerous even in the low level of concentration. Based on this, they are classified as primarily toxic pollutants in terms of pollution level (Modrzewska and Wyszkowski 2014). The main concern for heavy metals is the expansion of the source of emission,

Rahmat Zarkami

rzarkami2002@yahoo.co.uk

1 Department of Environmental Science, Faculty of Natural Resources, University of Guilan, P.O. Box 1144, Sowmeh Sara, Iran

2 Department of Animal Sciences and Aquatic Ecology, Faculty of Bioscience Engineering, Ghent University, Coupure Links, 653, 9000 Ghent, Belgium toxicity and environmental stability (Folkeson et al. 2009). These metal pollutants directly affect water characteristics, decrease biological activity and reduce the bioavailability of food in water and pose a serious threat to the health of organisms when entering the food chains (Tokhi et al. 2008) because they can be accumulated in aquatic ecosystems as well as in the tissue of organisms such as bivalve molluscs and a variety of fish species. Then, the metals are in turn transmitted through the food chains to birds, fish-eating animals, and eventually to humans (El Nemr et al. 2007). Another problem is that such metals are not metabolized in the body of aquatic organisms or human. In fact, they are not excreted from the body of organisms so that they are deposited and accumulated in the tissue of organisms such as fat, muscles, bones and joints causing many complications and diseases in the body (Essien et al. 2009). Heavy metals can cause a variety of effects on aquatic organisms such as retarded growth, behavioral and genetic changes, and occasionally biological decline in aquatic life, and also genetic changes and cancer incidences in people (Guveni and Akinci 2011). 
Despite, some metals consisting of copper, zinc and nickel are essential elements for organisms. In contrast, some of metals such as cadmium, lead, mercury and arsenic pose a serious threat to the health of living things (El Nemr et al. 2007). Though some metals in the environment are of natural origin, the metals particularly those resulting from industrial pollution can be poisonous, even destruct living things and upset the balance of aquatic organisms (Morillo et al. 2004). The main source of heavy metals discharging in aquatic environments are various factories and industries whose effluents contain high amounts of the heavy metals (Mishra et al. 2010).

The Anzali wetland is one of the most important wetlands in the north of Iran with an area of about 20,000 hectares. This wetland is located in the south of the Caspian Sea and in the province of Guilan (Pourang et al. 2010). Due to the high diversity of fauna and flora communities in this valuable wetland and relatively long retention time of inflowing water, the Anzali wetland effectively modulates the physical and chemical properties of water entering the Caspian Sea (Mansuri et al. 2013). With the arrival of heavy metals into the Anzali wetland, a portion of the metals enters the Caspian Sea causing biological magnification in the marine food chain through trophic levels. This has led to many concerns about the accumulation of metals in sediments, plants, animals and ultimately humans (Shokrzade et al. 2009).

Various wetland plants can accumulate heavy metals such as lead and cadmium serving as a bioremediation agent (Khosravi 2005). The chemical composition of heavy metals, plant age, physiology of absorption and excretion of elements from the body of organisms, physical and chemical factors and the function of heavy elements in various organs of aquatic organisms can have a significant impact on the absorption of heavy metals by aquatic plants (Almeida et al. 2011). Many studies have been conducted to determine the accumulation of heavy metals in aquatic plants (Axtell et al. 2003; Bonanno and Giudice 2009; Engi et al. 2015). For instance, earlier report (Favas and Pratas 2013) showed the importance of absorption of heavy metals by some aquatic plants such as Ranunculus trichophyllus, Azolla caroliniana and Juncusus. In another study (Hamidian et al. 2014), the sequence of absorption of some heavy metals by Nelumbo nucifera was obtained as $\mathrm{Cu}>\mathrm{As}>\mathrm{Cr}>\mathrm{Pb}>\mathrm{Cd}$, respectively.

A. filiculoides is an invasive free-floating plant in the Anzali wetland belonging to salviniaceae family. This fern fixes nitrogen with the symbiosis of Anabaena cyanobacteria and is used for agricultural purposes (Zazouli et al. 2013). A. filiculoides is found in several parts of the world including south Asia and particularly in tropical and subtropical regions. It has high reproduction rate and can grow quickly under favorable environmental conditions (Larsson 2011). The plant was imported from Philippines to Guilan province in 1983 with the aim of nitrogen fixation in the rice fields (Khosravi 2005). Then, A. filiculoides occupied a large area of natural catchments and northern paddy fields in a short time (Hashemloian and Azimi 2009) due to inappropriate management by the government as well as lack of natural predators. Based on this, A. filiculoides has grown very quickly in the northern of Iran and occupied a large area of the Anzali wetland. It has adversely affected the water quality of the wetland and has caused many ecological problems for native animal and also plant species such as Nelumbo nucifera (Indian lotus) and Lemna minor (duckweed) (Najafi and Baghestani 2009; Sadeghi et al. 2014). Despite many problems caused by A. filiculoides in Iranian wetlands, this water fern is considered as a valuable species to absorb various pollutants particularly the heavy metals ones. Thus, determination of concentration of the heavy metals in the Anzali wetland is necessary due to the disturbing effects of such metals on the native aquatic organisms. The present study aims to determine the amount of heavy metals in water sample and also the accumulation capacity and potential biomonitoring capability of the heavy metals by A. filiculoides.

\section{Materials and methods}

\section{The study area}

The Anzali international wetland lies at $37^{\circ} 22^{\prime}-37^{\circ} 30^{\prime} \mathrm{N}$ and $49^{\circ} 15^{\prime}-49^{\circ} 33^{\prime}$ E coordinates. This wetland consists of four distinct parts: central, eastern, western and Siahkeshim (south-east section of the central part) (Pourang et al. 2010). This ecosystem is an important spawning and nursery habitat for various fish species, and a breeding and wintering area for many waterfowls migrating from Siberia and other parts of the world. Many types of pollution sources enter the wetland resulting from the direct discharge of agricultural, urban and industrial wastewaters. In the present study, three sampling locations were randomly selected. The samples were taken from water body and A. filiculoides at each three parts of the wetland including central, eastern and western parts in June 2014 (Fig. 1).

\section{Water samples}

Water samples were taken in the middle depth of water column using Ruttner sampler with three replicates at each station. The samplers were already washed with distilled water and rinsed with $2 \%$ nitric acid to avoid contaminating the samples. The three samples (taking from three stations) were put in a container. Then, the samples passed through a Whatman filter paper 42 microns into a plastic bottle and immediately transferred to the laboratory (APHA/AWWA/ WEF 1998). To digest the water sample, $500 \mathrm{ml}$ of water 


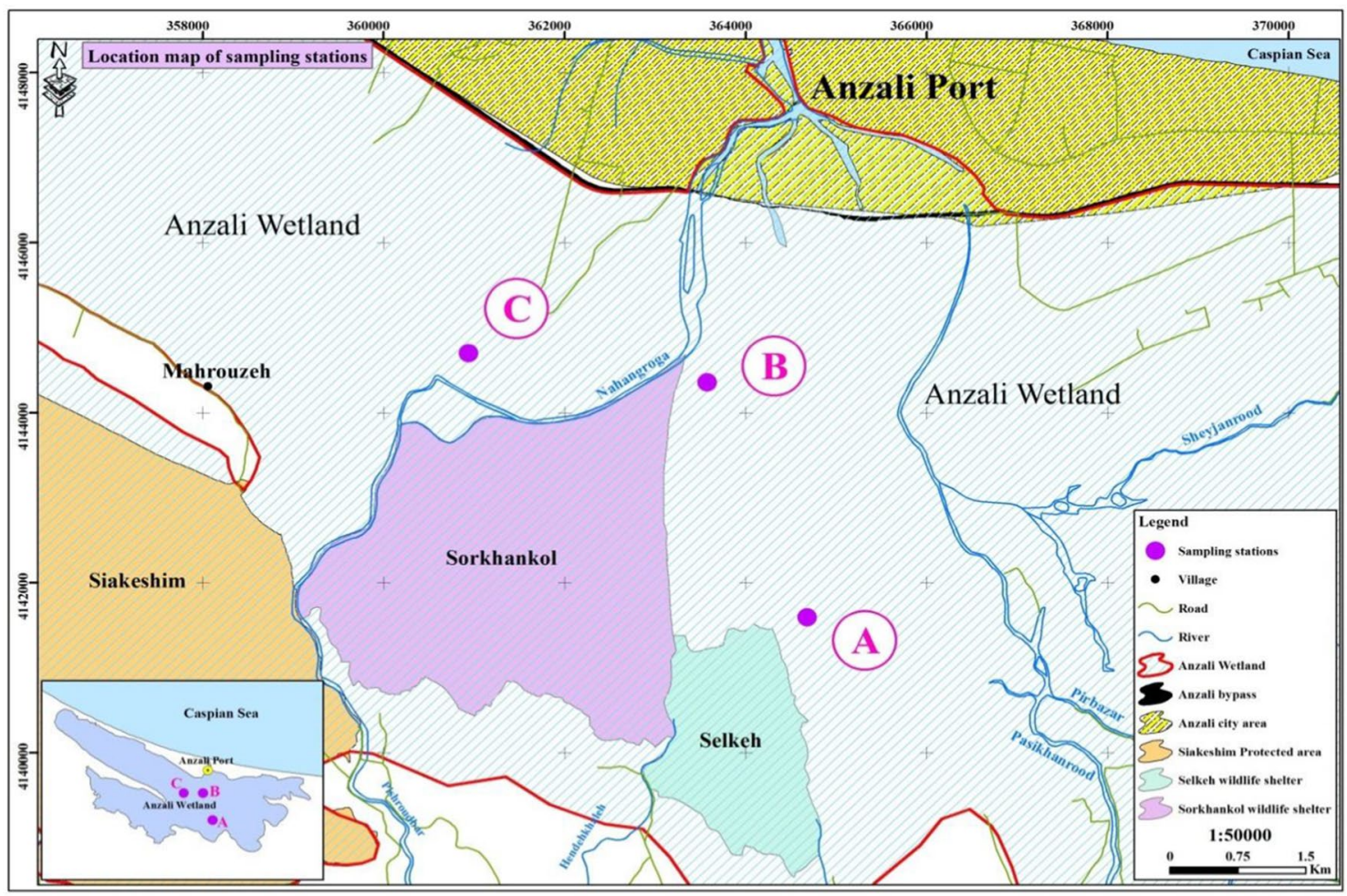

Fig. 1 Map of study areas with indication of the sampling sites in three parts of the Anzali wetland (a eastern part, $\mathbf{b}$ central part, $\mathbf{c}$ western part)

was taken from each sampling site and placed in a hot water bath at a temperature below $100^{\circ} \mathrm{C}$ until the sample volume reached $50 \mathrm{ml}$. After adjusting the acidity of the samples to $\mathrm{pH}<2$, they were stored in a refrigerator at $4^{\circ} \mathrm{C}(\mathrm{Ahmad}$ et al. 2010).

\section{A. filiculoides samples}

A. filiculoides specimens were collected at the same locations which were taken for the water samples (eastern, central and western wetland). Then, the samples were placed in a polyethylene container. The samples were transferred to the laboratory and they were initially rinsed with tap water and followed by the distilled water. The samples were then spread on a lace fabric for $72 \mathrm{~h}$ to dry. The dried A. filiculoides samples were placed in an oven at $180{ }^{\circ} \mathrm{C}$ for $3 \mathrm{~h}$. Then, the specimens were smashed and sieved. $1 \mathrm{~g}$ of sieved samples (from each sampling station) was added into digestion tubes (Khosravi 2005). The tubes were thus placed in a $90{ }^{\circ} \mathrm{C}$ water bath. To digest the samples, $1 \mathrm{ml}$ of $65 \%$ nitric acid and after $20 \mathrm{~min}, 1 \mathrm{ml}$ of hydrochloric acid and $2 \mathrm{ml}$ of $65 \%$ nitric acid were added to the tubes. The pipes were then placed in warm water bath at a temperature below 100 ${ }^{\circ} \mathrm{C}$. The tubes were then removed from the bath and placed in a reagent machine at $120^{\circ} \mathrm{C}$ for $2 \mathrm{~h}$. The samples were once again transferred to the bathroom until the volume of samples reached $50 \mathrm{cc}$. The samples were passed through a 42-micron Whatman filter paper and stored in a cylindrical polyethylene vessel (Shafi et al. 2015). After digestion process, the samples (water and A. filiculoides) were transferred to the laboratory (Faculty of Environmental Health, University of Guilan). Then standard solutions in specific concentration ranges $(0.01,0.1,1.0,5.0 \mathrm{mg} / \mathrm{l})$ was prepared for the given metals in the laboratory. In the next step, the calibration operation of the device was performed to draw the calibration curve.

Finally, the samples were injected into the ICP OES (SPECTRO ARCOS, AMETEK), and the concentrations of heavy metals were read (all laboratory materials used belonged to the Merck Germany).

\section{Data processing and analysis methods}

The normality of data for the recorded heavy metals parameters was examined by Kolmogorov-Smirnov test (SPSS 23.0 software for windows). After normalizing the data, a one-way ANOVA was conducted to determine the differences between the observations. The Tukey post hoc test (at the $95 \%$ confidence level) was used to compare the mean differences of samples at each part of wetland. 
Table 1 Concentration of heavy metals $(\mathrm{Cr}, \mathrm{Pb}, \mathrm{Zn}, \mathrm{Hg}, \mathrm{Cu}$, $\mathrm{Cd}, \mathrm{Ag}, \mathrm{Ti})$ (mean \pm standard deviation) in water and $A$ filiculoides samples (mg/l) in the eastern, central and western parts of the Anzali wetland.

\begin{tabular}{lllll}
\hline Metals & Samples & Eastern & Central & Western \\
\hline $\mathrm{Cr}(\mathrm{mg} / \mathrm{l})$ & Water & $0.020 \pm 0.010^{\mathrm{Ab}}$ & $0.003 \pm 0.001^{\mathrm{Bb}}$ & $0.003 \pm 0.001^{\mathrm{Bb}}$ \\
& A. filiculoides & $0.130 \pm 0.020^{\mathrm{Aa}}$ & $0.080 \pm 0.010^{\mathrm{Ba}}$ & $0.040 \pm 0.010^{\mathrm{Ca}}$ \\
$\mathrm{Pb}(\mathrm{mg} / \mathrm{l})$ & Water & $0.020 \pm 0.002^{\mathrm{Ab}}$ & $0.003 \pm 0.001^{\mathrm{Bb}}$ & $0.004 \pm 0.001^{\mathrm{Bb}}$ \\
& A. filiculoides & $0.150 \pm 0.010^{\mathrm{Aa}}$ & $0.070 \pm 0.030^{\mathrm{Ba}}$ & $0.065 \pm 0.030^{\mathrm{Ba}}$ \\
$\mathrm{Zn}(\mathrm{mg} / \mathrm{l})$ & Water & $0.290 \pm 0.010^{\mathrm{Ab}}$ & $0.209 \pm 0.020^{\mathrm{Bb}}$ & $0.169 \pm 0.010^{\mathrm{Cb}}$ \\
& A. filiculoides & $0.736 \pm 0.220^{\mathrm{Aa}}$ & $0.695 \pm 0.170^{\mathrm{Ba}}$ & $0.554 \pm 0.230^{\mathrm{Ca}}$ \\
$\mathrm{Hg}(\mathrm{mg} / \mathrm{l})$ & Water & $0.004 \pm 0.001^{\mathrm{Ab}}$ & $0.001 \pm 0.001^{\mathrm{Bb}}$ & $0.001 \pm 0.001^{\mathrm{Bb}}$ \\
& A. filiculoides & $0.011 \pm 0.002^{\mathrm{Aa}}$ & $0.004 \pm 0.001^{\mathrm{Ba}}$ & $0.005 \pm 0.001^{\mathrm{Ba}}$ \\
$\mathrm{Cu}(\mathrm{mg} / \mathrm{l})$ & Water & $0.034 \pm 0.001^{\mathrm{Ab}}$ & $0.031 \pm 0.001^{\mathrm{Bb}}$ & $0.027 \pm 0.001^{\mathrm{Cb}}$ \\
& A. filiculoides & $0.185 \pm 0.020^{\mathrm{Aa}}$ & $0.125 \pm 0.010^{\mathrm{Ba}}$ & $0.120 \pm 0.010^{\mathrm{Ba}}$ \\
$\mathrm{Cd}(\mathrm{mg} / \mathrm{l})$ & Water & $0.001 \pm 0.000^{\mathrm{Aa}}$ & $0.001 \pm 0.001^{\mathrm{Aa}}$ & $0.002 \pm 0.001^{\mathrm{Aa}}$ \\
& A. filiculoides & $0.001 \pm 0.000^{\mathrm{Aa}}$ & $0.001 \pm 0.001^{\mathrm{Aa}}$ & $0.001 \pm 0.001^{\mathrm{Aa}}$ \\
$\mathrm{Ag}(\mathrm{mg} / \mathrm{l})$ & Water & $0.012 \pm 0.001^{\mathrm{Ab}}$ & $0.012 \pm 0.002^{\mathrm{Aa}}$ & $0.012 \pm 0.001^{\mathrm{Aa}}$ \\
& A. filiculoides & $0.012 \pm 0.001^{\mathrm{Aa}}$ & $0.011 \pm 0.001^{\mathrm{Aa}}$ & $0.011 \pm 0.001^{\mathrm{Aa}}$ \\
$\mathrm{Ti}(\mathrm{mg} / \mathrm{l})$ & Water & $0.014 \pm 0.001^{\mathrm{Ab}}$ & $0.006 \pm 0.002^{\mathrm{Bb}}$ & $0.003 \pm 0.001^{\mathrm{Cb}}$ \\
& A. filiculoides & $0.020 \pm 0.050^{\mathrm{Aa}}$ & $0.014 \pm 0.030^{\mathrm{ABa}}$ & $0.011 \pm 0.001^{\mathrm{Ba}}$ \\
\hline
\end{tabular}

The values specified with different letters indicate a significant difference between the sampling stations (Tukey post hoc test at the 95\% confidence level)
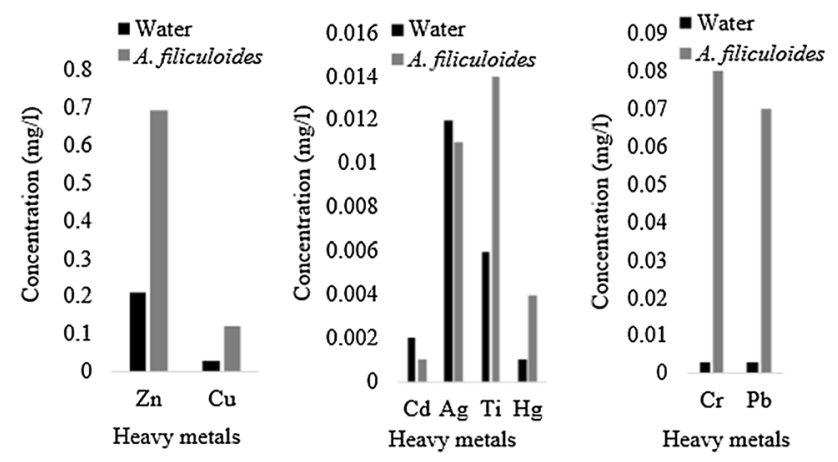

Fig. 2 Heavy metals in the samples of water and A. filiculoides in the eastern part of the wetland

\section{Results}

The obtained results concerning the concentration of heavy metals in water and A. filiculoides samples are presented in Table 1. The comparison of the accumulation of the heavy metals in the samples related to water body and A. filiculoides is also shown in Figs. 1,2 and 3. The results of Tukey post hoc test $(p<0.05)$ showed that compared to other heavy metals, $\mathrm{Zn}$ had the highest concentration in water and A. filiculoides in eastern, central and western parts of the wetland (Table 1). As presented in the table, there was a significant difference between the concentration of all heavy metals in all three parts of the wetland. In total, the amount of heavy metals in the eastern part was higher than other two parts of wetland $(p<0.05)$.
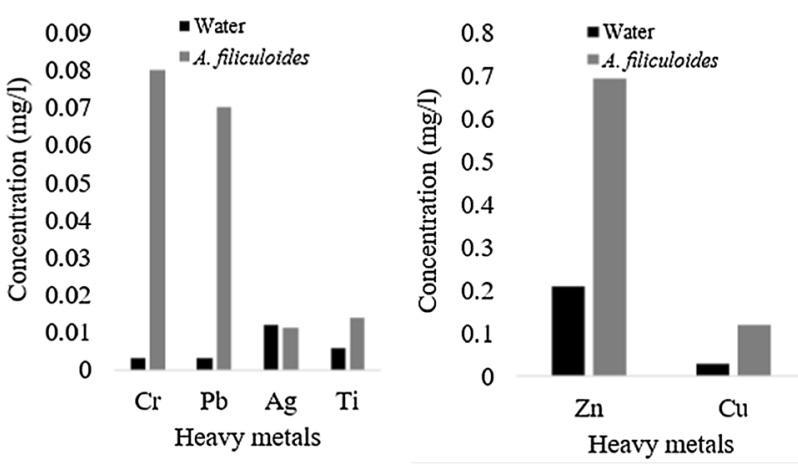

Fig. 3 Concentration of heavy elements in the samples of water and A. filiculoides in the central part of the wetland

Also, with comparing the concentrations of heavy metals in water and A. filiculoides samples, it was found that the accumulation of the heavy metals (except $\mathrm{Cd}$ and $\mathrm{Ag}$ ) in A. filiculoides was significantly higher than water samples $(p<0.05)$. As mentioned above, the accumulation of $\mathrm{Cd}$ and $\mathrm{Ag}$ in water and A. filiculoides did not differ significantly from each other.

As shown in Fig. 2, the concentration of heavy metals in the eastern part of the wetland (except $\mathrm{Cd}$ and $\mathrm{Ag}$ ) were significantly different in the water and A. filiculoides samples so that the values of metals in A. filiculoides were significantly higher than water sample. $\mathrm{Zn}$ had the highest concentration in both water and A. filiculoides so that the concentration of $\mathrm{Zn}$ was $0.0290 \pm 0.010$ in water and $0.736 \pm 0.220 \mathrm{mg} / \mathrm{l}$ in A. filiculoides. Cd had the lowest amount of concentration in water and A. filiculoides samples $(0.001 \pm 0.000)$. 
The average concentration of $\mathrm{Cr}, \mathrm{Pb}, \mathrm{Zn}, \mathrm{Hg}, \mathrm{Cu}, \mathrm{Cd}, \mathrm{Ag}$ and $\mathrm{Ti}$ in the water sample were $0.020,0.020,0.290,0.004$, $0.034,0.001,0.012$ and $0.014 \mathrm{mg} / \mathrm{l}$ in the eastern part of wetland, respectively. This indicates that the sequence of concentrations of heavy metals in water was obtained as $\mathrm{Zn}$ $>\mathrm{Cu}>\mathrm{Cr}>\mathrm{Pb}>\mathrm{Ti}>\mathrm{Ag}>\mathrm{Hg}>\mathrm{Cd}$. The average concentration of $\mathrm{Pb}, \mathrm{Cu}, \mathrm{Zn}, \mathrm{Hg}, \mathrm{Ti}, \mathrm{Cd}, \mathrm{Ag}$ and $\mathrm{Cr}$ for A. filiculoides in the eastern part of wetland were obtained as $0.130,0.180$, $0.730,0.011,0.156,0.001,0.012$ and $0.020 \mathrm{mg} / 1$, respectively. As a result, the concentration sequence of the metals in the eastern part for A. filiculoides was reported as $\mathrm{Zn}>\mathrm{C}$ $\mathrm{u}>\mathrm{Pb}>\mathrm{Cr}>\mathrm{Ti}>\mathrm{Ag}>\mathrm{Hg}>\mathrm{Cd}$.

In the central part of the wetland, the values of heavy metals except $\mathrm{Cd}$ and $\mathrm{Ag}$ were significantly different in the samples of water and A. filiculoides indicating that the values of metals in A. filiculoides were significantly higher than water (Fig. 3). Concentration of $\mathrm{Zn}$ in water $(0.209 \pm 0.020$ $\mathrm{mg} / \mathrm{l})$ and A. filiculoides $(0.695 \pm 0.170 \mathrm{mg} / \mathrm{l})$ had the highest amount compared to other metals. Cd had the lowest amount both in water and A. filiculoides samples $(0.001 \pm 0.001)$. The average concentration of $\mathrm{Cr}, \mathrm{Pb}, \mathrm{Zn}, \mathrm{Hg}, \mathrm{Cu}, \mathrm{Cd}, \mathrm{Ag}$ and $\mathrm{Ti}$ in water sample were $0.003,0.003,0.209,0.001$, $0.031,0.001,0.012$ and $0.006 \mathrm{mg} / \mathrm{l}$ in the central part of the wetland, respectively. So, the sequence of metals concentrations in water was observed as $\mathrm{Zn}>\mathrm{Cu}>\mathrm{Ag}>\mathrm{Ti}>\mathrm{Pb}>\mathrm{C}$ $\mathrm{r}>\mathrm{Hg}>\mathrm{Cd}$, respectively. Also, the mean concentrations of these heavy metals in A. filiculoides in the central part were reported as $0.080,0.070,0.695,0.004,0.125,0.001,0.011$ and $0.014 \mathrm{mg} / \mathrm{l}$, respectively. The sequence of concentration of metals in A. filiculoides in the central part of the wetland was $\mathrm{Zn}>\mathrm{Cu}>\mathrm{Cr}>\mathrm{Pb}>\mathrm{Ti}>\mathrm{Ag}>\mathrm{Hg}>\mathrm{Cd}$.

In the western part of the wetland (Fig. 4), the values of all heavy metals except $\mathrm{Cd}$ and $\mathrm{Ag}$ were significantly different in water and $A$. filiculoides samples so that the values of metals in A. filiculoides were significantly higher than water sample. In the western part of the wetland, $\mathrm{Zn}$ had the highest concentration in water $(0.169 \pm 0.010)$ and $A$. filiculoides $(0.554 \pm 0.230 \mathrm{mg} / \mathrm{l})$, respectively. On the other
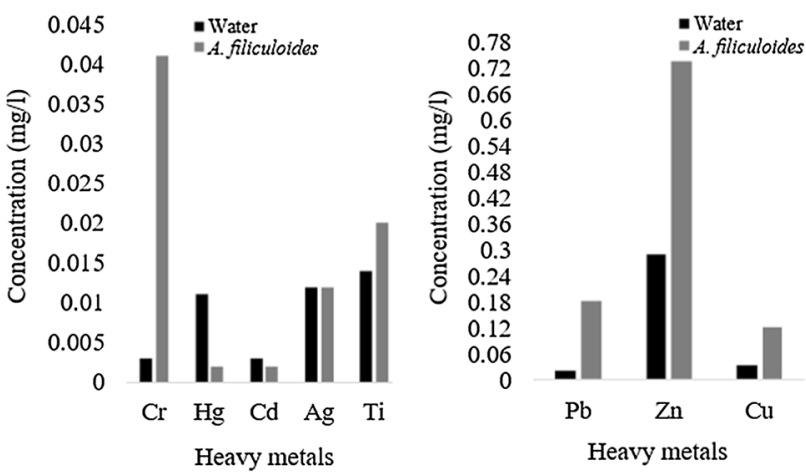

Fig. 4 Concentration of heavy elements in the samples of water and A. filiculoides in the western part of the wetland hand, $\mathrm{Cd}$ had the lowest values in water $(0.001 \pm 0.001)$ and A. filiculoides $(0.002 \pm 0.001)$, respectively. In the western part of the wetland, the average concentration of metals (in water samples) consisting of $\mathrm{Cr}, \mathrm{Pb}, \mathrm{Zn}, \mathrm{Hg}, \mathrm{Cu}, \mathrm{Cd}, \mathrm{Ag}$ and $\mathrm{Ti}$ were obtained at 0.003, 0.004, 0.169, 0.001, 0.027, $0.002,0.012$ and $0.003 \mathrm{mg} / \mathrm{l}$, respectively. The sequence of metal concentration in water sample was $\mathrm{Zn}>\mathrm{Cu}>\mathrm{Pb}>\mathrm{Cr}$ $>\mathrm{Ti}>\mathrm{Cd}>\mathrm{Hg}$, respectively. In addition, in the western part of the wetland, the average concentration of heavy metals in A. filiculoides was $0.040,0.065,0.550,0.005,0.156,0.001$, 0.011 and $0.011 \mathrm{mg} / 1$, respectively. Also, in the western part of the wetland, the sequence of metal concentrations in $A$. filiculoides was obtained as $\mathrm{Zn}>\mathrm{Cu}>\mathrm{Pb}>\mathrm{Cr}>\mathrm{Ti}>\mathrm{Ag}>$ $\mathrm{Hg}>\mathrm{Cd}$.

\section{Discussion}

The potential and capabilities of some of the aquatic plants like A. filiculoides should be identified for the treatment of wetlands because such plants are considered as irreplaceable filters that play an important role for the health of wetland. Based on this, in recent years, much attention has been paid to the accumulation of heavy metals by aquatic plants through phytoremediation process (Foroughi and Toghiani 2012). For instance, many authors (Robinson et al. 2003; Pratas et al. 2012; Hamidian et al. 2014; Torbati and Keshipour 2020) proved the importance of phytoremediation using hydrophytes like Lemna gibba L, Lemna minor, Callitriche stagnalis and Fontinalis antipyretica. Other studies (Sasmaz et al. 2008; Pratas et al. 2012) also confirmed the importance of Typha latiolia for the phytoremediation process in wetland and calculated the biological condensation and transmission factors to remove $\mathrm{Zn}$. Based on this, in the present study, the concentration of heavy metals in water and A. filiculoides samples was evaluated in three parts of the Anzali wetland. Then, the capability of A. filiculoides (as a phytoremediation agent) was compared with the samples taken from water body concerning metal accumulation in the sampling locations.

As stated in the results, the highest and lowest amount of heavy metals in water and A. filiculoides samples were observed in $\mathrm{Zn}$ and $\mathrm{Cd}$ in all sampling sites, respectively. The importance of $\mathrm{Zn}$ for A. filiculoides has been already confirmed by several studies (MacFarlane et al. 2003; Kara 2005; Sadeghi et al. 2014) so $\mathrm{Zn}$ is an essential element for the growth of A. filiculoides playing an important role in many metabolic and physiological processes of this water velvet (MacFarlane et al. 2003; Kara 2005; Sadeghi et al. 2014). $\mathrm{Zn}$ is also an important metal as an activator of some vital enzymes including carbonic anhydrase and phospholipases for A. filiculoides. Based on this, the effect of increasing $\mathrm{Zn}$ concentration on the tissue of A. filiculoides in the

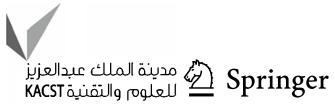


sampling sites can be due to the necessity of the given metal for the growth of the water fern (MacFarlane et al. 2003; Kara 2005).

Unlike essential elements such as $\mathrm{Cu}$ and $\mathrm{Zn}$, many heavy metals might have devastating effect on the ecological balance of aquatic life and biodiversity in the study wetland. The results showed that the amounts of metals except $\mathrm{Cd}$ and $\mathrm{Ag}$ in the eastern part of wetland were significantly higher than the central and western parts of wetland. This indicates that the eastern part is the most polluted areas concerning $\mathrm{Cr}, \mathrm{Pb}, \mathrm{Zn}, \mathrm{Hg}, \mathrm{Cu}$ and $\mathrm{Ti}$ than the central and western parts of the wetland. One of the main reasons for the high concentration of heavy metals in the eastern part of the wetland is due to the presence of various industries activities and also intensive farming practices in the vicinity of this part of wetland which discharge too much wastewaters into the wetland (Vesali Naseh et al. 2012).

The statistical test showed that the concentration of $\mathrm{Cr}$, $\mathrm{Pb}, \mathrm{Zn}, \mathrm{Hg}, \mathrm{Cu}$ and $\mathrm{Ti}$ in A. filiculoides sample was significantly higher than water sample in all three parts of the wetland. The discharge of urban wastewater, the wastes of petroleum products, the pollution resulting from various industrial, agricultural and landfill are the main sources of heavy metals pollution in the Anzali wetland (Ganjali and Ghasemi 2016). One of the effective ways in reducing the concentration of these heavy metals in the Anzali wetland might be phytoremediation process by hydrophytes like $A$. filiculoides. Due to intensive distribution of A. filiculoides in the most parts of the Anzali wetland, this fern is largely able to prevent contamination and treat the wetland (Mansuri et al. 2013).

Light intensity, oxygen content and temperature are important factors for the growth of A. filiculoides (Sadeghi et al. 2014). The given parameters play important role in the absorption of heavy metals by this water fern. Also, the energy from photosynthesis and released oxygen provides the necessary conditions to the active absorption of the heavy metals by this water fern (Arts et al. 2008).

The earlier report showed that the biological transmission factor for $\mathrm{Zn}$ was higher than one which indicates the efficiency of $A$. filiculoides in the transfer of the metal from root to upper organs (Sasmaz et al. 2008). The results of the present study are in line with earlier reports (Shafi et al. 2015) demonstrating that $A$. filiculoides had the highest levels of $\mathrm{Zn}$ in its tissues compared to $\mathrm{Cu}, \mathrm{Pb}, \mathrm{Cd}$ and $\mathrm{Cr}$. The higher amount of metal accumulation in the roots compared to the leaf tissue of $A$. filiculoides indicates poor transfer of ions in the leaf of the plant (Shafi et al. 2015). This has been confirmed by previous studies for A. filiculoides as well as other plants (Sela et al. 1989) who reported that the content of heavy metals in A. filiculoides root was two to five times higher than leaf tissue (Sela et al. 1989). According to a research study (Yabanli et al.
2014), accumulation of $\mathrm{Cr}$ in the roots of some macrophytes such as Myriophyllum spicatum was higher than the stem and lower than the leaves. In addition, A. filiculoides has symbiotic relationship with some cyanobacteria such as Anabaena in its roots (Larsson 2011) which can help the plant.

Moreover, another study (Shafi et al. 2015) showed that A. filiculoides can accumulate the highest amount of $\mathrm{Zn}$ in its tissues compared to $\mathrm{Cu}, \mathrm{Pb}$ and $\mathrm{Cd}$ which could be due to the necessity of $\mathrm{Zn}$ for the vital activities of the fern. The higher accumulation of metals in the roots compared to the leaf tissue of $A$. filiculoides indicates poor transport of ions in this water fern so that the outcomes are consistent with the results of the present research since adsorption of $\mathrm{Zn}$ after Ti by A. filiculoides in all three parts of the wetland showed relatively higher values than other metals.

Previous report (AitAli et al. 2002) confirmed that the uptake of $\mathrm{Cu}$ might show an increase in A. filiculoides by increasing the concentration of $\mathrm{Cu}$ in the growth medium. In the present study, the highest absorption of $\mathrm{Cu}$ in $\mathrm{A}$. filiculoides was obtained as $0.156 \mathrm{mg} / \mathrm{l}$ in the eastern part of the wetland which indicates the high potential of this plant in removing $\mathrm{Cu}$ in the given part of the wetland. According to earlier research (Hoseinizadeh et al. 2011), the sequence of the concentration of heavy metals in the roots of some macrophytes such as Trapa natans in the Anzali wetland was similar to the results of the present study like $\mathrm{Cd}<\mathrm{Cr}<\mathrm{Cu}<\mathrm{Zn}$ (Hoseinizadeh et al. 2011).

The outcomes of the current research indicated that the most contaminated areas for the heavy metals for A. filiculoides sample were the eastern followed by the central and western parts of Anzali wetland, respectively. This can be justified by the fact the western part is the deepest part of the wetland and the Siahkeshim (a protected area) is located in this part. Due to its special characteristics, this protected area is one of the least polluted areas in the wetland, while the eastern part of the Anzali wetland has the lowest depth. Moreover, Pirbazar River (one of the highly polluted rivers in the Anzali wetland watershed) enters the eastern part so that the discharged waters from Pirbazar River into the region have high concentrations of pollutants such as Ti, $\mathrm{Zn}$ and $\mathrm{Cu}$ (Vesali Naseh et al. 2012). A large volume of sewage from the Pirbazar River enters the eastern part of the wetland. This river originates from two highly polluted rivers including Goharrood and Zarjoub. About $15 \%$ of the pollution and $25 \%$ of the sedimentary loads are transported to the central part of the wetland through the Pirbazar River, which has recently increased the growth of aquatic plants including A. filiculoides in this part of the wetland. As a result, the self-purification capacity of the central has increased than the eastern part of the wetland which might reduce pollution loads in this area (Hoseinizadeh et al. 2011; Esmaeilzadeh et al. 2016). 
In another study (Sartaj et al. 2005), the highest levels of $\mathrm{Cr}$ and $\mathrm{Zn}$ contamination were found in the sediments of Pirbazar (the eastern part of the wetland). The research showed that the amount of $\mathrm{Zn}$ and $\mathrm{Cr}$ decreased with the distance from the estuary (Sartaj et al. 2005). In another study (Vesali Naseh et al. 2012), the sequence of metals in the water samples of the Anzali wetland was obtained as $\mathrm{Zn}>\mathrm{Ni}>\mathrm{As}>\mathrm{Pb}>\mathrm{Cd}$. The highest concentration of $\mathrm{Zn}$ and $\mathrm{Pb}$ was similar to the present research in the eastern part of the wetland (Vesali Naseh et al. 2012).

There are various metals and smelting industries, factories and chemical and petrochemical industries in the vicinity of the Anzali wetland watershed. The effluents have high amounts of heavy metals such as $\mathrm{Zn}, \mathrm{Hg}, \mathrm{Cr}$ and $\mathrm{Pb}$ (Zare Khosheghbal et al. 2013). $\mathrm{Hg}, \mathrm{Cr}, \mathrm{Cu}, \mathrm{Ni}$ and $\mathrm{Zn}$ are the most widely used industrial metals found in the effluents of various industries, especially metal plating industries, as well as agricultural and municipal wastewater in the Anzali wetland watershed (Karbassi, et al. 2008). In addition, one of the sources of metal input to the Anzali wetland is the Anzali port which is in the vicinity of the Anzali wetland. The reason is that there are a lot of shipping activities and oil tanker traffic in Anzali port.

Cyanobacteria have high absorption and accumulation capacity for the heavy metals which are used for the purification of industrial wastewater (Afdal 2008; Laloknam et al. 2009). Therefore, the absorption and accumulation potential of the A. filiculoides roots are very important (Sood et al. 2012). The high ability of A. filiculoides in absorbing and accumulating heavy metals has made it possible to introduce this plant as an effective macrophyte in biomonitoring of water quality in the Anzali wetland for the heavy metals and in refineries. The previous research showed that different Azolla species can be used to remove colored contaminants from water and sewage (Zazouli et al. 2013).

According to the results of the present study, it can be concluded that A. filiculoides is a very suitable plant for the purposes of phytoremediation in the Anzali wetland. In general, a suitable plant species (as a bioremediation) should have specific characteristics such as rapid and abundant growth, high dispersion and potential for absorption and accumulation of pollutants (Hamidian et al. 2014). As a conclusion derived from the study, A. filiculoides has all these conditions in the study areas.

\section{Conclusion}

Heavy metal pollution in aquatic ecosystems is a serious concern for the inhabitants of the ecosystem and the health of humans. Therefore, it is essential to evaluate the extent and sources of the heavy metal pollution in the aquatic ecosystems. Based on the conclusion derived from the present study, due to the expansion of industrial, tourist and petroleum activities around the Anzali wetland, the concentration of heavy metals may increase to hazardous levels. Therefore, continuous monitoring of the area using aquatic plants such as A. filiculoides is essential for the protection of plant and animal life the Anzali wetland.

Acknowledgements The authors would like to acknowledge Roghayeh Sadeghi for improving and editing the manuscript.

Funding The author(s) received no specific funding for this work.

\section{Declarations}

Conflict of interest The authors declare that they have no conflict of interest.

Open Access This article is licensed under a Creative Commons Attribution 4.0 International License, which permits use, sharing, adaptation, distribution and reproduction in any medium or format, as long as you give appropriate credit to the original author(s) and the source, provide a link to the Creative Commons licence, and indicate if changes were made. The images or other third party material in this article are included in the article's Creative Commons licence, unless indicated otherwise in a credit line to the material. If material is not included in the article's Creative Commons licence and your intended use is not permitted by statutory regulation or exceeds the permitted use, you will need to obtain permission directly from the copyright holder. To view a copy of this licence, visit http://creativecommons.org/licenses/by/4.0/.

\section{References}

Afdal M (2008) Cyanobacteria as a removal agent of heavy metal. Thesis of School of Graduate Study University Putra, Malaysia

Ahmad MK, Islam S, Rahman S, Haque MR, Islam MM (2010) Heavy metals in water, sediment and some fishes of Buriganga River, Bangladesh. Int J Environ Res 4:321-332

AitAli N, Bernal MP, Ater M (2002) Tolerance and bioaccumulation of copper in Phragmites australis and Zea mays. Plant Soil 239:103-111

Almeida CMR, Mucha AP, Teresa Vasconcelos M (2011) Role of different salt marsh plants on metal retention in an urban estuary (Lima estuary, NW Portugal). Estuar Coast Shelf Sci 91:243-249

APHA/AWWA/WEF (1998) Standard methods for the examination of water and wastewater, 19th ed. Washington, DC, USA

Arts GHP, Belgers JDM, Hoekzema CH, Thissen JTNM (2008) Sensitivity of submersed freshwater macrophytes and endpoints in laboratory toxicity tests. Environ Pollut 153:199-206

Axtell NR, Sternberg SPK, Claussen K (2003) Lead and nickel removing using Microspora and Lemna minor. Bioresour Technol 89:41-48

Bonanno G, Giudice RL (2009) Heavy metal bioaccumulation by the organs of phragmites australis (common reed) and their potential use as contamination indicators. Ecol Indic 10:639-645

El Nemr AH, El Sikaily A, Khaled A (2007) Total and leachable heavy metals in muddy and sandy sediments of Egyptian coast along Mediterranean Sea. Environ Monit Assess 129:151-168

El Tokhi M, Abdelgawad E, Lotfy MM (2008) Impact of Heavy metals and Petroleum hydrocarbons contamination of the East Port Said Port area. Egypt Appl 4:1788-1798 
Engi MS, Uyanik A, Kutbay HG (2015) Accumulation of heavy metals in water, sediments and wetland plants of kizilirmak delta (Samsun, Turkey). Int $\mathrm{j}$ Phytoremediation 17:66-75

Esmaeilzadeh M, Karbassi A, Moattar F (2016) Assessment of metal pollution in the Anzali Wetland sediments using chemical partitioning method and pollution indices. Acta Oceanol Sin 35:28-36

Essien J, Antai S, Olajire A (2009) Distribution seasonal variations and ecotoxicological significance of heavy metals in sediments of cross river estuary mangrove swamp. Water Air Soil Poll 197:91-105

Favas PJC, Pratas J (2013) Uptake of uranium by native aquatic plants: potential for bioindication and phytoremediation. EDP Sciences, E3S Web of conferences in Portugal 1:13007

Folkeson L, Bækken T, BrenčičM DA, Frančois D, Kuřímská P, Vojtěšek M (2009) Sources and fate of water contaminants in roads. Water in Road Structures 5:107-146

Foroughi M, Toghiani S (2012) Phosphorus removal from aquaculture wastewater and latex by Ceratophyllum demersum. Afr j Biotechnol 11:1639-1643

Ganjali S, Ghasemi A (2016) Heavy metal contamination in the sediments of anzali international wetland northern Iran based on type regional development. Iranian Journal of Toxicology 10:1-6

Guveni ED, Akinci G (2011) Comparison of acid digestion techniques to determine heavy metals in sediment and soil samples, Gazi University. Journal of Science 24:29-34

Hamidian AH, Atashgahi M, Khorasani N (2014) Phytoremediation of heavy metals $(\mathrm{Cd}, \mathrm{Pb}$ and $\mathrm{V})$ in gas refinery wastewater using common reed (Phragmites australis). Int j Aquat Biol 2:29-35

Hashemloian BD, Azimi AA (2009) Alien and exotic Azolla in northern Iran. Biotechnol 8:187-190

Hoseinizadeh GR, Azarpour E, Ziaeidoustan H, Moradi M, Amiri E (2011) Phytoremediation of heavy metals by hydrophytes of anzali wetland (Iran). World Appl Sci J 12:1478-1481

Kara Y (2005) Bioaccumulation of $\mathrm{Cu}, \mathrm{Zn}$ and $\mathrm{Ni}$ from the wastewater by treated Nasturtium officinale. Int j Environ Sci Technol 2:63-67

Karbassi AR, Monavari SM, Nabi Bidhendi GHR, Nouri J, Nematpour K (2008) Metal pollution assessment of sediment and water in the Shur River. Environ Monit Assess 147:107-116

Khosravi M (2005) Biosorption of $\mathrm{Pb}, \mathrm{Cd}, \mathrm{Cu}$ and $\mathrm{Zn}$ from the wastewater by treated Azolla filiculoides with $\mathrm{H} 2 \mathrm{O} 2 / \mathrm{MgCl} 2$. Int $\mathrm{j}$ Environ Sci \& Technology 1:265-271

Laloknam S, Sirisopana S, Phornphisutthimas S, Takabe T, Incharoensakdi A (2009) Removal of mercury, arsenic, and cadmium in synthetic wastewater by cyanobacterium Aphanothece halophytica. NU Science Journal 6:96-104

Larsson J (2011) Cyanobacterial genome evolution subsequent to domestication by a plant (Azolla). Universitet service, UC-AB, Stockholm University, Department of botany Sweden

MacFarlane GR, Pulkownik A, Burchett MD (2003) Accumulation and distribution of heavy metals in the grey mangrove, Avicennia marina (Forsk)Vierh.: biological indication potential. Environ Pollut 123:139-151

Mansuri N, Khorasani N, Monavari SM, Karbasi A, Panahandeh M (2013) Heavy metal concentration in soil and plant species (Phragmites australis, Trapa natans) from Anzali Wetland (Iran). World J Environ Pollut 3:01-04

Mishra S, Swivedi SP, Singh RB (2010) A review on epigenetic effect of heavy metal carcinogens of human health. Open Nutraceuticals J 3:188-193

Modrzewska B, Wyszkowski M (2014) Trace metals content in soils along the state road 51 (northeastern Poland). Environ Monit Assess 186:2589-2597

Morillo J, Usero J, Gracia I (2004) Heavy metal distribution in marine sediments from the southwest coast of Spain. Chemosphere $55: 431-442$
Najafi H, Baghestani MA (2009) Biology and Management of weeds of Iran. Ministry of Agriculture Publications, Agricultural Research, Education and Promotion 1:559

Pourang N, Richardson CA, Mortazavi MS (2010) Heavy metal concentrations in the soft tissues of swan mussel (Anodonta cygnea) and surficial sediments from Anzali wetland. Iran Environ Monit Assess 163:195-213

Pratas J, Favas PJC, Paulo C, Rodrigues N, Prasad MNV (2012) Uranium accumulation by aquatic plants from uranium-contaminated water central Portugal. Int $\mathrm{j}$ Phytoremediation 14:221-234

Robinson BH, Duwig C, Bolan NS, Kannathasan M, Saravanan A (2003) Uptake of arsenic by New Zealand water cress (Lepidium sativum). Sci Total Environ 301:67-73

Sadeghi R, Zarkami R, Van Damme P (2014) Modelling habitat preference of an alien aquatic fern, Azolla filiculoides (Lam.), in Anzali wetland (Iran) using data-driven methods. Ecol Modell 284:1-9

Sartaj M, Fathollahi F, Filizadeh Y (2005) An Investigation of the Evolution of Distribution and Accumulation of Heavy Metals $(\mathrm{Cr}$, $\mathrm{Ni}, \mathrm{Cu}, \mathrm{Cd}, \mathrm{Zn}$ and $\mathrm{Pb}$ ) in Anzali Wetland's Sediments. Iranian Journal of Natural Resources 58:623-634 ((in Persian))

Sasmaz A, Obek E, Hasar H (2008) The accumulation of heavy metals in Typha latifolia L. grown in a stream carrying secondary effluent. Ecol Eng 33:278-284

Sela M, Garty J, Tel-Or E (1989) The accumulation and effect of heavy metal on the water fern Azolla filiculoides. New Phytol 112:7-12

Shafi N, Pandit AK, Kamili AN, Mushtaq B (2015) Heavy metal accumulation by Azolla pinnata of Dal Lake ecosystem. India $\mathrm{j}$ Environ 1:8-12

Shokrzade M, Saeedi Saravi SS, Zehtab Yazdi Y (2009) Lindane residues in cultivated cucumber and in the most consumed fish in Caspian Sea. Iran Toxicol Ind Health 25:517-523

Sood A, Uniyal P, Prasanna R, Ahluwalia AS (2012) Phytoremediation potential of aquatic macrophyte, Azolla. Ambio (a Journal of Human Environment) 41:122-137

Torbati S, Keshipour S (2020) Application of Lemna gibba L. and a bio-based aerogel for the removal of metal(loid)s from stream waters near three gold deposits in northwestern Iran Environ. Technol. Innov 20:101068

Vesali Naseh MR, Karbassi A, Ghazaban F, Baghvand A (2012) Evaluation of heavy metal pollution in Anzali Wetland, Guilan. Iran Iranian Journal of Toxicology 5:565-576

Yabanli M, Yozukmaz A, Sel F (2014) Heavy metal accumulation in the leaves, stem and root of the invasive submerged macrophyte Myriophyllum spicatum L. (Haloragaceae): an example of Kadin Creek (Mugla, Turkey). Braz Arch Biol Technol 57:434-440

Zare Khosheghbal M, Charkhabi AH, Sharifi F, Ghazban F (2013) An Investigation of sediment pollution in the Anzali Wetland. Pol $\mathrm{j}$ Environ 22:283-288

Zarkami R, Hesami H, Sadeghi Pasvisheh R (2020) Assessment, monitoring and modelling of the abundance of Dunaliella salina Teod in the Meighan wetland, Iran using decision tree model. Environ Monit Assess 192:160-172

Zazouli MA, Balarak D, Mahdavi Y (2013) Effect of Azolla filiculoides on removal of reactive red 198 in aqueous solution. J Adv Environ Health Res 1:44-50

Publisher's Note Springer Nature remains neutral with regard to jurisdictional claims in published maps and institutional affiliations. 